\title{
Come Together-The Development of Swedish Energy Communities
}

\author{
Dick Magnusson $1, * \mathbb{D}$ and Jenny Palm ${ }^{2}$ \\ 1 Department of Thematic Studies-Technology and Social Change, Linköping University, \\ SE-581 83 Linköping, Sweden \\ 2 The International Institute for Industrial Environmental Economics, Lund University, \\ SE-221 00 Lund, Sweden; jenny.palm@iiiee.lu.se \\ * Correspondence: dick.magnusson@liu.se, Tel.: +46-13-285741
}

Received: 19 December 2018; Accepted: 13 February 2019; Published: 18 February 2019

\begin{abstract}
Community energy (CE) and grassroots innovations have been widely studied in recent years, especially in the UK, Germany, and the Netherlands, but very little focus has been placed on Sweden. This paper describes and analyses the development and present state of several types of community energy initiatives in Sweden. The methodology uses interviews, document studies, analysis of previous studies, and website analysis. The results show that fewer initiatives have been taken in Sweden than in other countries, but that even with a rather 'hostile' institutional setting CE has emerged as a phenomenon. Wind cooperatives are the most common form of initiative, with solar photovoltaics cooperatives and eco-villages also prominent. The various types of initiatives differ considerably, from well-organized wind cooperatives that have grown into professional organizations to small-scale hydroelectric power plants owned by a rural community. The initiatives may have modest impact on the energy transition in quantitative terms, but they are crucial in knowledge sharing and as inspirations for future initiatives.
\end{abstract}

Keywords: community energy; grassroots innovations; energy cooperatives; Sweden

\section{Introduction}

In the Energy Union package of 2015 the European Commission emphasized the citizens' role for a clean energy transition. Citizens are expected to "take ownership" of the energy transition and participate actively in the market [1]. The strong role of the citizens was emphasized again in 2017 by the European Commission [2]. The idea is to enable citizens to become knowledgeable participants in energy transitions. Citizen involvement is, however, still a niche phenomenon and is dependent on a community's access to capital, technical knowledge and institutional settings [3-5].

At the same time there are many trends challenging the existing structure with dominating energy companies. Photovoltaics with promising development in energy storage together with an increasing presence of technologies allowing active engagement from the users contribute to the rise of new business models with the potential to challenge the traditional energy market value chain (for example, peer-to-peer trading). New energy communities are also developing around the world. These energy communities have different characteristics at different places [6] but can involve partnership between citizens, industry, and municipalities.

Several of the possible benefits from community energy (CE) have been described: CE projects produce widespread and lasting mainstream impacts, fosters second-order learning, provide a useful way for citizens to engage, decrease energy costs, reduce the impact on the environment, provide enjoyable activities for the participants, increase integration in a community, increase social and civic gratification, build strong communities, foster networks, provide an opportunity for citizens 
to work together toward common goals with collective benefits, reduce barriers to the adoption of new technology, and reduce payback periods for such technology [7]. Yet, these benefits for both the members and the society, as well as their potential to actually support a transition of the energy system, is still to be proven.

This article analyzes existing Swedish CE projects and discusses the potential CEs have in a Swedish energy transition perspective. Swedish CE has not gained much attention in previous studies. Mignon [8] discussed the types of actors that invest in renewable energy (RE), including wind cooperatives, and lists systemic factors for cooperative RE projects. Kooij et al. [4] compared the institutional settings for grassroots innovations (GI) in Sweden, Denmark, and the Netherlands, and Mignon and Rüdinger [9] compared systemic factors with an impact on RE cooperative projects in Germany, France, and, Sweden. A more comprehensive mapping and analysis has not been conducted previously on Sweden, as mentioned studies have focused on either specific organization forms or on an institutional level, and not on specific cases.

Sweden is an interesting case to discuss in relation to CE's potential to contribute to an energy transition. Sweden's institutional setting is, as mentioned above, perhaps not so beneficial for CEs as other countries and Sweden already has a high share of renewable energy in the system. Mignon and Rüdinger [9] argue that Sweden is an interesting case for this reason, since there are examples of countries with low shares of RE, but with strong development for CE $[4,10]$. The electricity market in Sweden is centralized, with a few dominant utilities, with little contact between utility and user. An important aspect of $C E$ is increased citizen engagement in energy production, which, for example, the UK implemented through the "Community Energy Strategy" published by the Department of Energy and Climate Change in 2014 [11]. This strategy points out that individual and local communities are "important" in maintaining energy security, tackling climate change, and keeping down costs for consumers, but policies like these do not exist in Sweden.

It is interesting to make a comprehensive study of CE in Sweden, because it is important as a contribution to a democratization of RE production. It is further interesting to understand why $\mathrm{CE}$ develops, despite unfavorable conditions.

The importance of relating CE to different local contexts is highlighted by Yamamoto [12], who concludes that it is important to consider cultural, social, historical, and economic aspects when analyzing why some initiatives are established while others never manage to materialize in certain contexts. Thus, this study covers a new country and institutional setting, and can add to previous research in terms of understanding CE development in countries that have come far in the energy transition.

In this article we analyze how CE has developed in Sweden, in the light of fairly unfavorable conditions. While other countries have implemented policies to support CE, the subject has been rather ignored in Sweden, but even so CE has been established. The aim of this article is to present a mapping of Swedish CE initiatives, to analyze the emergence of CE in Sweden, and to understand how institutional factors affected the development.

The paper has six sections. The introduction is followed by a literature review of GI and CE. Section 2 presents previous research on CE. Section 3 presents the methodology used to describe the material and the research design used. Section 4 presents and analyzes the empirical results. Section 5 discusses and analyzes the results, before Section 6 presents our conclusions.

\section{Previous Research on Community Energy}

In this section we will present previous research on $\mathrm{CE}$, in order to end with some identified research gaps.

Community energy (CE) is one example of grassroots innovations (GI). Several scholars, such as Ornetzeder and Rohracher [13], have used a GI-based perspective to compare successful initiatives for RE and car sharing, and shown how these triggered further change in Austria, Denmark and Switzerland. Heiskanen et al. [7] and Martiskainen [14] analyzed the role of local communities for GI, 
while Seyfang and Longhurst [15] analyzed community currencies. There are different definitions of $\mathrm{CE}$, but they all remain related to the definition of GIs. Martiskainen [14] (p.80) argue that CE are:

"initiatives run by civil society actors (such as charities, not-for-profit organizations, voluntary neighborhood networks and co-operatives) which develop either or both energy saving and renewable energy generation measures."

Much focus in the literature has been on the aspect of understanding the definition and rationale behind the movement. Walker and Devine-Wright [16] argue that energy projects can be characterized as community projects by defining the target group (who the project is for) and the active participants (who the project is by). Rogers et al. [17] characterize projects as community initiatives when the local community participates actively in the planning, decision-making and/or exploitation of the project, and benefits from its revenues or other results. CE projects are initiatives undertaken by volunteers, in which a person or several people try to respond to issues such as climate change. The participants in a CE project adhere to the idea think globally and act locally [18].

The geographical scale and scope of $\mathrm{CE}$ have been given considerable attention, as CE projects usually focus on a specific locality, such as a neighborhood, in which the initiator wants to increase awareness of sustainability issues or conduct a practical project. Such projects are based on the idea that the citizens have the greatest potential to affect their living conditions at a community level [18]. Hieschler et al. [19] identify three aspects of CE that distinguish it from government or business-led interventions. First, CE projects are multi-faceted and combine behavioral initiatives, energy-efficiency measures and microgeneration. Second, they bring together a group of people with a common purpose and in this way overcome the structural limitations of individualistic measures. Third, they enable citizen participation in the development of sustainable energy systems and develop solutions suitable for the local context.

Many of the studies that have mapped CE have been in the UK, for example by Walker et al. [5], who mapped UK initiatives, and found over 500, and by Seyfang et al. [6], who focused on a sample of 354 of these groups, studying who they are, what they do and why. Oteman et al. [20] mapped GIs and institutional settings in three European countries. They identified more than 300 GIs in the Netherlands, most of them being wind cooperatives or local renewable energy companies with a mix of technologies and aims, but the majority starting after 2009. There are several thousands of initiatives in Denmark, of which many are small-scale combined heat and power plants, wind cooperatives, and a variety of technologically innovative projects. In Germany solar cooperatives comprise a large group of initiatives, along with wind cooperatives. Becker and Kunze [21,22] argued, however, that the concept of $\mathrm{CE}$ has been too focused on the British context, and has been ambiguous and too conflated with the community that the initiatives are embedded in. All citizens are not involved in the initiatives, and they risk becoming neglected. An alternative concept, collective and politically-motivated renewable energy (CPE) projects, is presented as an alternative, in order to go beyond the British concept, and to avoid restricting selection and analysis to the local level. Three geographical trends were described: projects might be locally bound but motivated by broader societal change; there are also examples that are regional or national in their extent, thus going well beyond the "community" scale; and, finally, projects might have aims to go beyond their own organizations, their focus was rather to trigger change in cities' overall energy policy and regulation.

The establishment of $\mathrm{CE}$ can be one method to make energy generation and consumption more local, by organizing projects that implement RE technologies. Wirth [3] emphasizes that the collective organization of RE is effective with regard to mobilizing existing resources, and that such organization often makes economic and logistical sense.

The support instruments are discussed in the literature and Bauwens et al. [23] found that these as well as planning policies for renewable energy cooperatives in four European countries, Denmark, Belgium, the UK, and Germany, have decreased over time, resulting in a more hostile environment that placed cooperatives at a distinct disadvantage compared to traditional energy developers. Tarhan [24] 
highlights that communities that can afford to invest in shared energy generation projects tend to be well-to-do, and that there are few case studies of such projects in economically disadvantaged communities. However, a general challenge identified is difficulties in obtaining resources such as money, material, knowledge and time. A lack of internal drive to external diffusion is a further challenge, as is how to transfer learning from an individual CE project to others [25]. The potential for community-led local sustainability initiatives is high, but so far this potential has not been fulfilled, and uptake has been scattered [3,18].

Smith et al. [26] have analyzed the interrelation between policy and grassroots innovations generally, and CE in particular, and aimed at broadening the analysis in order to "to consider CE emerging as a collective actor, how it is becoming influential, and how it is changing as a result of policy and business" [26] (p. 409). Through scrutinizing three analytical perspectives within niche development literature, they argue that $\mathrm{CE}$ has developed along trajectories that have given them access to policy-makers and energy utilities, thus influencing policies. The initiatives have become more professional, taking on forms that are more in line with existing regimes, through partnerships, hybrid models, and attempts to scale up, but the argument is that there is a risk of losing sight of the alternative and unique characteristics of CE. A critical niche perspective helps one remain open to alternative pathways of sustainable energy transitions and maintain a critical edge.

The literature presented often focuses on British cases and policies, although several studies from other countries have emerged. However, it becomes clear that the differences in institutional settings and energy regime and landscape are crucial in order to make further advances in the analysis. A crucial difference is that Sweden has made considerable progress in the energy transition: a steady transition began in the 1980s, and by 2015, 54\% of total energy usage came from renewable fuels, increasing to $65-70 \%$ in the heating and electricity sectors [27]. Much of this responsibility has been on the municipalities, who, by international comparison, are in strong positions in terms of self-government, taxation rights, and planning monopolies. Energy companies have been started and owned by municipalities, meaning that much responsibility in the energy transition ends up with the municipalities [28]. This institutional setting is different from, for example, the UK and other European countries, and the CEs developed in these settings will differ from those that have been traditionally analyzed in earlier research. Our aim with the Swedish examples of CEs is to discuss how the CE framework might be developed to also be applied in an institutional setting similar to Sweden's, with a tradition of strong public ownership.

CE projects in Sweden have not been mapped, but some studies have been published on, for example, prosumers [29]. Bergek et al. [30] studied investments in renewable electricity production in Sweden and showed that the category "associations" (which included, for example, economic associations and churches) accounted for around 5\% of the number of plants in 2012, but less than $2 \%$ of generating capacity. Such associations are thus a small group, and the main players are utilities, independent power producers, and diversified companies.

There is a significant body of literature on CE and GI, but there are some research gaps. One of them, as pointed out by Hossain [31], is that most studies focus on successful cases, but failed project can potentially help us understand obstacles and institutional limitations even further. As our study presents a comprehensive overview, we have also found cases that are not successful. Another gap relates to how responsibilities are divided between different levels (local, regional, and national) and how that might affect the development of CE. This is interesting to discuss from a Swedish perspective, where there are strong municipalities.

\section{Materials and Methods}

The work presented in this article was carried out using two methods: the mapping of existing data and interviews with CE representatives in Sweden. Before presenting methods used we will give a short overview of Sweden's energy system. 
Of Sweden's total electricity production in 2015, (159 TWh), hydroelectric power plants produced $47 \%$ of the electricity, nuclear power plants $34 \%$, wind power $10 \%$, and combined heat and power $8 \%$ [32]. Further, Sweden has, by international comparisons, historically had low and stable energy prices for customers for heating and electricity $[4,33]$. The special characterization of high shares of RE, centralized energy production, strong involvement from local governments in energy production and low energy prices, makes Sweden an interesting case to study in relation to how and why CE develops.

\subsection{Data Collection}

Existing data were mapped in a stepwise process. The first step focused on mapping CE projects, as such comprehensive mapping had not previously been carried out. We used the following sources for secondary data:

- Databases, such as The Swedish Energy Agency's database 'Cesar', covering organizations registered in the Swedish electricity certificate system. This allowed us to find organizations producing RE and by sorting out the organization types "Incorporated associations" ("Ekonomisk förening' in Swedish), "non-profit association" (Samfällighet), and "non-profit organization" (ideell förening), we could find an initial list of potentially interesting organizations, but since not all CE initiatives are signed up for the certificate system, this was not comprehensive enough for our purpose. We also used the database for wind power, 'Vindstat', and could filter the organization forms in order to find the ones relevant to us. A few extra organizations appeared compared to the 'Cesar' database. The database for organizations in Sweden, 'Retriever-Business', was also used in order to find interesting cases, by filtering organization forms and the field of business (i.e., energy production).

- Previous research, such as research reports, and dissertations. These covered specific forms of CE, such as eco-villages [34-38], solar PV cooperatives [39], and wind cooperatives [8,9]. In some cases, as with eco-villages, the sources included tables of active organizations that were relevant for our study, but in others only a few were covered, but it provided additional cases for our study.

- Reports from umbrella organizations and interest groups. There existed reports on wind cooperatives that included lists of, at the time of publication, active organizations [40], reports mapping a wider range of EC forms [41].

- Magazines, such as 'Förnybar Energi', from the umbrella organization SERO.

These sources gave us an initial list of potential projects. Many of the sources needed to be updated because they were a few years old and none of them had all the information we needed. By snowballing, going through magazines, and further reports, we could find some additional cases, as well as updating and ensuring that organizations were still active, which was not always the case.

We also sent out a survey to all regional energy offices in Sweden. These energy offices are owned by the Regions and support projects with a focus on RE and energy efficiency. In the inquiry we asked representatives in the office to send suggestions for potential CE projects that could be relevant to us. The inquiry gave us a few more cases, but we could also confirm that we had covered many of the potentially relevant organizations. The mapping was carried out until March 2017.

The mapping generated a first database of the projects or organizations focusing on RE that have been started by citizen groups, communities, or small-scale cooperatives. This generated a list of 225 items. Sampling was based on evaluating available information, such as websites, reports, or newspaper items, and criteria were based on the CE-literature, and included identified, or planned, investments in renewable energy, organizational form, mainly incorporated associations (ekonomisk förening), non-profit association (Samfällighet), and non-profit organization (ideell förening), which keywords that were used on websites or by-laws (for example, focus on community, non-profit, cooperation), and ownership structure (to make sure that the owners are mainly citizens).

The criteria for the final selection of cases was based on the same procedure as in the initial mapping, but with more in-depth studies of a broader range of sources (including newspapers). 
An important factor was to understand how, why, and by whom the project or organization was started. In a few cases the organizations had been started as incorporated associations but have become limited companies. These have been included in order to understand the start and change process. The mapping and analysis showed however that organization forms and goals of organizations were strongly related, as those projects that were started and run by limited corporations had goals and aims that focused on financial gain and seldom mentioned alternative aims, such as collective solutions or environmental factors. The exceptions here are wind cooperatives that often state that economic interests of their members is an important goal, and small-scale heating system projects, which were run as limited corporations but often combined financial goals with a focus on local aspects. A few wind and solar initiatives were jointly owned between a public corporation and community groups/citizens, and these were included if they were started in cooperation with citizens. Information from several sources (websites, official corporate databases, reports, newspapers) was obtained about the CE initiatives identified. This information included background information, location, goals, strategies, starting date, legal form, network membership, number of members, membership in any umbrella organizations, ownership, activities, degree of local connection, projects undertaken, and technology used.

We also carried out 43 interviews, 38 of them with 36 CE initiatives (two organizations were interviewed twice), and five of them with umbrella organizations working with RE (see Appendix A for a list of interviews). The selected initiatives were sampled from the different types and technologies in order to get a dispersion, and according to the share of this type of initiative among the whole population of CE initiatives. We also aimed at selecting some of the projects identified as the most innovative and interesting. The selection of initiatives was also based on geographical location and starting year, in order to find eventual differences. The interviews were semi-structured interviews, focusing on the start-up of the organization, its inspiration, network membership, any obstacles experienced, drivers, and its present and future challenges. Five of the interviews were carried out face-to-face, and the others by telephone. The interviews took between 25 and 90 minutes.

The interviews were carried out with representatives in the organizations, mainly the chair or the secretary. We aimed at interviewing actors in positions that ensured an overview of the whole structure, and actors that had been active for quite some time and, thus, had knowledge of the history and motivations for starting the organization. We asked about general themes, based on our knowledge from the document studies, such as the starting phase, organization today, development of the organization and CE in general, and institutional support and barriers. More specifically we asked about the aims and motivations for starting the organization, which key actors that were involved, if they were inspired by other similar projects, if there were obstacles in the initial phases, if they had received grants or other forms of support, how the organization is organized today, if goals have been adjusted compared to the initial goals, if they cooperate with other CE initiatives, if and how they work with technology development, membership in umbrella organization, key drivers and obstacles for successful initiatives, institutional prerequisites, and future development of the organization.

\subsection{Data Analysis}

The collected data were analyzed using methods based in grounded theory [42], meaning that we inductively aimed at discovering patterns and differences among the cases. The interviews and the documents were coded in Atlas.ti. The documents and interviews were analyzed separately initially since they belonged to different steps in the methods. The documents helped us gain deeper knowledge among all the cases and in the interviews we could go deeper and ask about matters not covered in the documents. This meant that the aims of the analysis were a bit different, and the analysis of the documents have helped forming the interview questions.

In both processes of analysis, we used the analysis tools in Atlas.ti, such as count quotations and code-document tables, in order to see which keywords and topics that occurred more frequently, and these were then analyzed further in relation to the type of CE they belonged to. We could then 
find patterns of, e.g., common barriers, motivations, and future views, and the analysis showed clear patters within the CE types.

We used two further methods: GIS mapping, to find geographical patterns, and descriptive statistics for quantitative data, such as produced energy and capacity.

\subsection{Limitations}

The methodological approach used has limitations. The aim has been to be as complete in the mapping of initiatives as possible, but one can never be certain that every relevant single initiative has been included. We have tried to avoid missing out on important initiatives by using various sources and methods in order to be as comprehensive as possible.

Another aspect of the mapping is that it was carried out over time, meaning that changes potentially could have occurred between the start of the collection and the end, but also between the end of collection and time of publication of results. We went through the list after the collection ended to keep it updated, but we can assume that organizations do not always update websites upon closing down.

Some of the interviewed actors were not involved in starting the organizations, meaning that they could not provide first-hand information about the process. We triangulated the interviews with documents in order to get as comprehensive descriptions of the processes as possible, but studying cases historically means that these limitations have to be acknowledged [43].

\section{Results: Community Energy Initiatives in Sweden}

This section presents the results from the mapping of Swedish CE. We present the main types of $\mathrm{CE}$ and discuss the emergence, goals, organization forms, and geographical distribution. We then present results from the interviews, focusing on the motivations and how institutional settings have affected the initiatives.

\subsection{Characterization of $C E$}

We identified around 140 active CE initiatives, and around 20 previously active ones. The total generating capacity of the organizations is $160 \mathrm{MW}$, most of which is from wind cooperatives, with a smaller amount coming from solar PV cooperatives.

The largest number of CE initiatives are wind cooperatives, with 78 active and around 20 discontinued. The second largest group is eco-villages (32). Most of these are in rural settings, with only a few in urban areas. We identified 10 small-scale heating organizations and nine solar PV communities. Eight rural communities run various forms of production with a local focus (hydropower, heat or energy-saving plans).

The most common form of organization is as an incorporated association, which is the form used by 90 of the organizations, followed by 20 non-profit association (samfällighet), 10 tenant-owned apartments (bostadsrättsföreningar), and four non-profit organizations. Fourteen CE initiatives are organized as some kind of commercial enterprise (ranging from a limited company to an individual enterprise).

Figure 1 presents the starting years of the initiatives. Only a few $\mathrm{CE}$ initiatives were established before 1990, all of them being eco-villages.

Most initiatives are located in the Västra Götaland region, and the number here is somewhat higher than expected from the population distribution. CE initiatives in Norrland (Northern Sweden) are also over-represented relative to population, while they are underrepresented in the Stockholm region. The population density is high in the Stockholm region and, thus, land available for CE initiatives is limited. Wind cooperatives are, with a few exceptions, incorporated associations where members buy shares. The cost of membership differs between cooperatives. The historical cost has been approximately SEK $5000 / 1000 \mathrm{kWh}$, and the cost has fallen in recent years. Most cooperatives have only one plant, with an installed capacity between $125 \mathrm{~kW}$ and $20,000 \mathrm{~kW}$. This is the case for 
$75 \%$ of cooperatives, the most common capacity being $600 \mathrm{~kW}$. The three largest projects in our survey have 760, 2100, and 4000 members, respectively, with most cooperatives having 200-300 members.

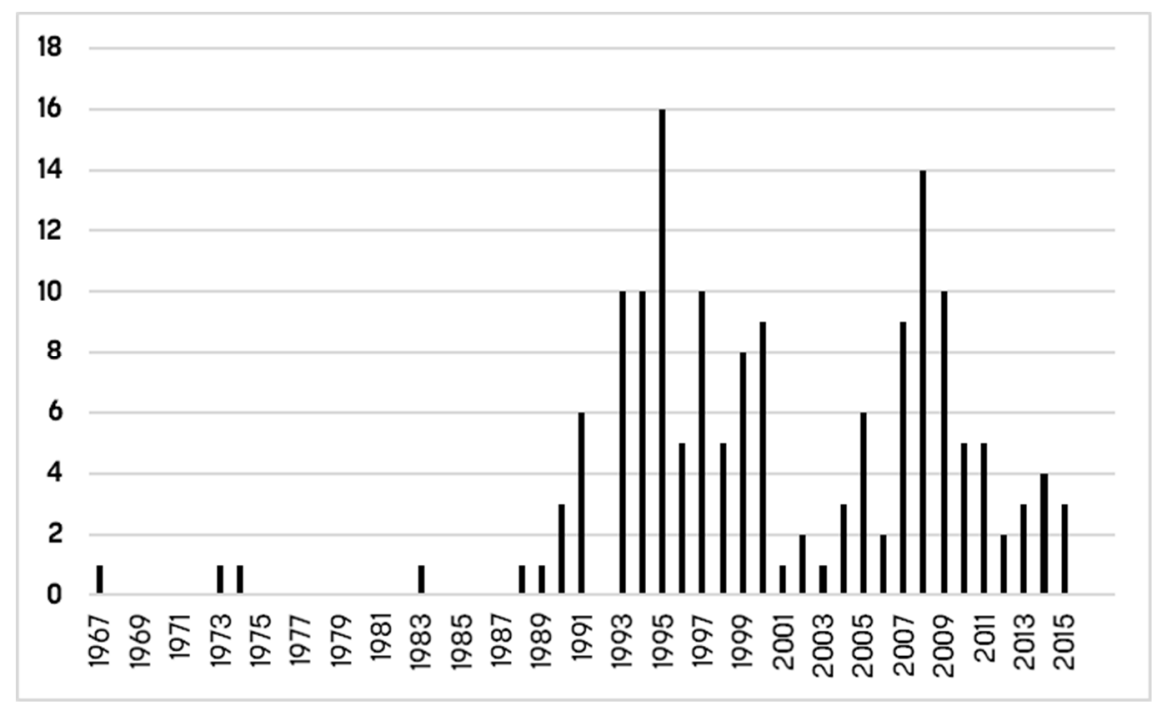

Figure 1. Starting years of CE initiatives (number per year).

The eco-villages included show large differences. The common aspects are that they are intentional communities addressing social, ecological, and economic sustainability, often with innovative system solutions for energy efficiency. For example, technical solutions in the studied cases span from resource efficient and/or reused building material, energy efficient housing constructions, renewable energy production for heating and/or electricity, or urine-separating toilets. They are organized around cooperation and social inclusion, including working units, and may vary in size from a few households to up to 50. Eco-villages that have been started in recent years tend to be small, are often located at farms, and have connections to the transition movement and the permaculture movement [44].

Small-scale heating systems are located in small, rural villages and communities. They operate small-scale district heating systems, with a central production plant and distribution of hot water in closed systems to users. Local heating businesses are, in many cases, run as limited corporations, and although the goals often include financial incentives, the local aspect of both supplying the communities as well as stressing usage of local biomass gives them a strong local connection.

Solar cooperatives in many ways resemble wind cooperatives: being organized as incorporated associations, selling shares to members, and investing in renewable electricity production. Six organizations are active, with a further three under formation. At least one initiative has failed. The average capacity of the solar initiatives is lower than that of wind cooperatives. The two largest have a capacity of around $600 \mathrm{~kW}$, while smaller ones have a capacity of around $100 \mathrm{~kW}$. Most of them still do not pay a dividend to the members; they re-invest all profits in new plants.

A few rural communities with high RE ambitions were identified. They run their projects as non-profit associations or incorporated associations. Technologies differ: some have installed mainly energy-efficiency measures while others are running renovated hydroelectric power plants, but the common feature is that they have come together in a joint effort. Four of the communities worked with hydro power, and in these cases an association owns the plant, and the profit goes back to the community and is used to invest in, for example, community centers or school buildings.

A few municipal energy companies have adopted business models similar to CE. Some wind cooperatives, as well as some solar PV cooperatives, have been started by municipal energy companies. These actors (Kalmar Energi, Öresundskraft, Sala-Heby, and Telge Energi) have similar motivations, in that champions within the companies stated that they were interested in RE production and wanted to expand the opportunities for their consumers to invest in it. In two cases, Kalmar Energi and 
Öresundskraft, wind cooperatives owned by municipal energy companies, influenced their parent companies and stimulated translation of the business model to solar energy projects.

\subsection{Institutional and Economic Prerequisites}

In this section we will present the factors that have been identified as determinants for success of $\mathrm{CE}$ projects, based on interviews with representatives of the cooperatives. Personal interests from the involved actors, such as environmental interests and drive to take matters into their own hands, are important components. Various kinds of economic support for RE in general has been crucial. The competence within the organizations has also been important and the capabilities to involve local energy companies, especially among electricity producing organizations. We found that factors that have either halted the development, or led to failed projects, are related mainly to institutional factors, such as prices, policies, and economic support that ends, such as the green electricity certificates.

\subsubsection{Strong Driving Forces}

The reasons for starting cooperatives varies. A main driver, which is common among the different types of initiatives studied, is an interest in doing things themselves, both in terms of renewable energy but also in terms of solving local needs that municipalities cannot handle. Among the wind cooperatives we saw an interest to take action themselves, which can be reflected in the following quotes:

One can say that it began with that we wanted to do something ourselves about the situation to improve opportunities to access renewable energy and then we realized that there was no one else who would do it for us, but we saw the opportunity to do it ourselves. (Interview 3)

Yes, for my part it was about, for the same reasons as today, that there are $20 \%$ of the population who do not want to do as everyone else, for example buy electricity from Vattenfall. A big supplier that you cannot get in touch with personally etc. And of the $20 \%$ I was one. So I wanted to try to produce my own electricity. (Interview 36)

These were the key pioneers in the projects, driven by their convictions. These actors are important in the organizations, as they have been present and in charge for a long time.

For an initiative working with small-scale heating in a rural area, it was clear that they could do something with their forest, and also without involving the municipality:

Respondent: the starting point was an increased value in one's own forest, it was really how it started and if the municipality had built this (heating system, authors note), then we would not have invested in the plant. But I think this solution as such is much better

(...)

Interviewer: What do you think is the main reason the project has been successful?

Respondent: It is really that you have everything in your own hand (Interview 8)

This must be seen in the light of Sweden having a long tradition of public ownership, especially for district heating in most municipalities, and centralized electricity systems based on, firstly, hydro-power and, later, nuclear power, which have led to low electricity prices and little room or incentives for other actors to enter the market [4]. Further, municipal autonomy is well developed in Sweden, and municipalities are self-governing, have taxation rights, and a monopoly in municipal planning. This has meant that the Swedish state and municipalities are responsible for energy production, and have been responsible for the transition that has occurred $[28,45]$. To do something without that involvement means that you need to have a specific drive. Swedish municipalities also play other important roles in the energy area. Since the late 1970s they have been required by law to have an energy-conservation policy and to take active measures to develop an energy-supply system 
that is sustainable in the long-term. Thus, municipalities often take a comprehensive view of the energy system, and formulate goals and visions from a system perspective that includes all components of the system: supply, conservation measures, and environmental strategies [45].

Another driver has been an interest in renewable energy and to make a difference in terms of environmental aspects. The interest in renewable energy is especially true for wind cooperatives, which can be seen in the quotes above, but for eco-villages and rural communities the environmental concerns are even more true. They have been inspired by different movements, and previous studies have shown that they have been inspired by the anti-nuclear movement [44], but also the sustainable development debates, relating to biological cycle questions, and in recent years self-sufficiency and ecological footprints, as well as climate change.

The association started in 1994, then the biological cycle question was a popular topic, similar to the climate today, and then we talked a lot in the village about this, and we realized that we had the conditions for this if you looking at our farm and that there was enough houses around, so we saw that we had the right conditions. (Interview 10)

For many of us, it is about becoming more self-sufficient and thus reducing our ecological footprint on the environment and perhaps even make a positive impression before we die, because we are doing quite a lot of long-term projects where we plant trees shrubs and rebuilds entire ecosystems. (Interview 34)

Specifically, our own actions to in some way reduce the climate impact, where it is very concrete and quite simple. So, the climate discussions, an electricity market that becomes more volatile and perhaps higher energy prices, I see as important. (Interview 12)

The last citation is also an example of the fact that many of the initiatives have different motives and drivers, as climate goals can be combined with economic goals and incentives. Keywords used by the initiatives were identified from strategy documents and websites. These are presented in Figure 2.

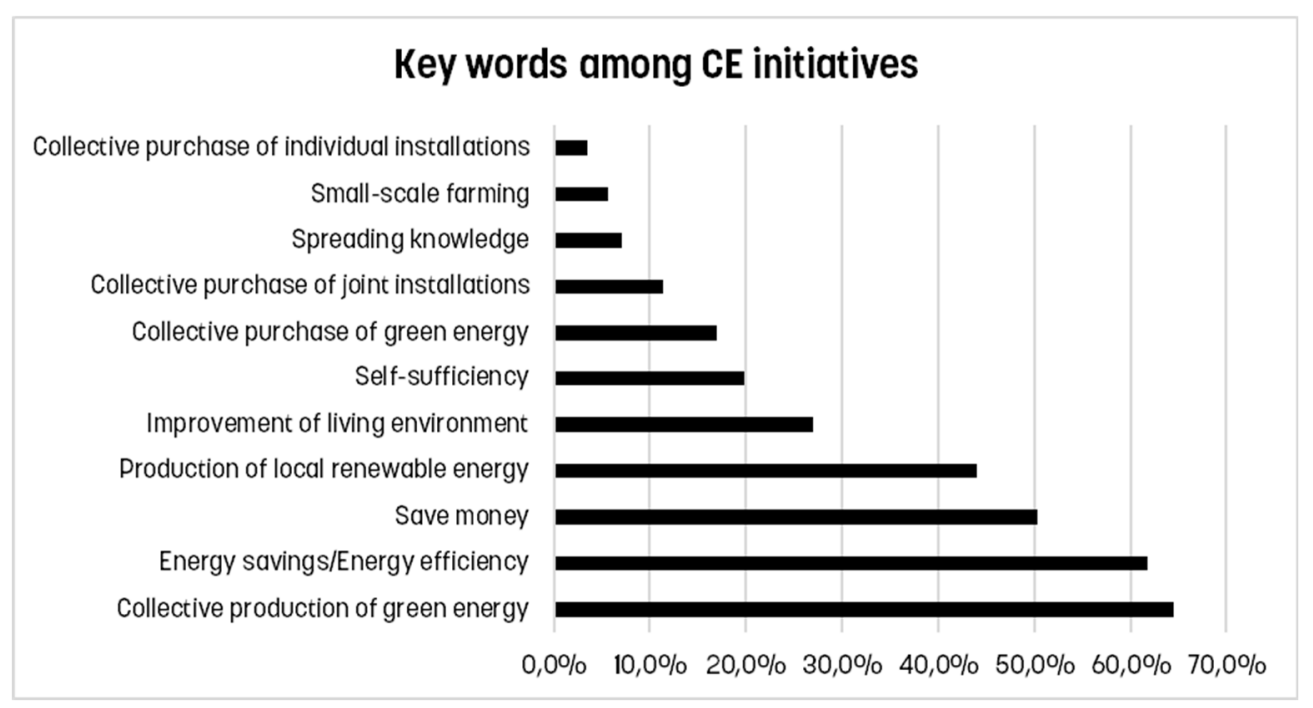

Figure 2. Keywords among the goals and aims of CE initiatives.

There is a significant focus on the production of green energy, energy savings, saving money, and production from a local perspective. Self-sufficiency is not common generally, only among eco-villages, and spreading knowledge does not have a high profile among the CE initiatives, which reflects the fact that these organizations focus mainly on their own activities. In addition, their aims do not reach further than energy saving and production. 


\subsubsection{Capabilities of the Members}

Among our studied cases, a common pattern is that successful cooperatives need to navigate through bureaucracy, grants applications, and technical system configurations and standards that they need to take care of themselves. This is, in itself, an obstacle, which means that perseverance, as well as rather high competence and good networking skills, are main components among the key actors within the organization. There are differences, as RE matters in rural communities are handled within an existing organization and do not require the same investments as wind cooperatives. The latter are rather professional, which is necessary to handle the planning process and capital-intensive investments, and it is reflected in the quote below, from one representative from an umbrella organization for wind power in Sweden, including some wind cooperatives, which argue that the cooperatives do not ask for support in the same way as one could expect:

Yes, first of all, the wind cooperatives themselves have very qualified board of directors, so they live very much in their own world. (Interview 37)

The same goes for eco-villages, which, in the period of starting up, need to navigate through a time-consuming and complex planning process. For example, the eco-village in Tuggelite, one of the first in Sweden, was comprised of researchers from Gothenburg University [46], and Solbyn, an eco-village that citizens built together with a building company, was also initiated by a well-educated, environmentally-concerned citizen group:

It was started about thirty years ago, through a group of people at Vetenskapens hus (House of Science) in Lund, who cooked vegetarian food together, and they wanted to create something for the future that was sustainable and they thought a lot about nuclear energy then. So they drew up energy-efficient houses and they collaborated with the municipality and others who could help, and in the end they got the go-ahead from HSB [Building Company-authors' note] whom supported it all. They did however compromise a lot with their ideas, and it took ten years before the village was realized, and unfortunately there was a lot of compromises about the energy aspects too. (Interview 30)

Good networking skills have been another success factor. This is important in the phase of attracting new members, as many of them require a substantial number of members. One of the solar PV cooperatives that was not successful did not manage to gain enough momentum in the requirement process, and combined with changed energy prices, the drive to continue faded out (interview 27). The solar PV cooperatives that have been successful have all had good contacts with energy companies. In a context of centralized energy, and especially electricity, systems, it seems like cooperation with incumbent market actors is favorable. The support can be through consultation or, as in the case of the most influential case, Sala-Heby, also through economic support from the municipal energy company Sala-Heby Energi:

Since Sala-Heby Energi was one of the drivers in the project we decided that we [i.e. the company Sala Heby Energi] are prepared to buy the electricity [produced by the PV cooperative]; we can buy that electricity over a longer time period and through the long agreement. We did also pay a lot in the beginning and less in the end and the point with that was, from the cooperative's side, that they knew that they got security for sales already when building the plants. (Interview 24)

Those cooperatives that have not been successful have not had support in any form from a local energy company. This has especially evident among solar PV cooperatives. In one of the cases (interview 42), the costs became too high to invest in the cable as the energy companies wanted to make the installation, but they had not been involved earlier in the process, and with a tighter communication, and more support, from the energy company, the potential for a successful process would have been higher. 


\subsubsection{Institutional Context}

Energy policies and economic support are among the strongest factors that influence the success rates for CEs. To make reality of the drivers and interest, the economic support has been crucial. Swedish energy policy during the 1990s focused much on reducing $\mathrm{CO}_{2}$ emissions, introducing $\mathrm{CO}_{2}$ taxation in 1991 and, after that, supporting RE investments through various projects. Wind power increased, from 129 plants and 47 GWh production in 1993, to 428 plants and 318 GWh 1998 and a steady rise to 3334 plants and 15,479 produced GWh in 2016 [32]. This was helped by investment support of $20 \%$ on plants over $60 \mathrm{~kW}$ in 1991, which was increased to $35 \%$ in 1993, and support via an "environmental bonus", covering the energy tax on electricity in 1994 [47].

The investment support was mentioned as important for wind cooperatives that were started around that time (Interview 3), and combined with the liberalization of the electricity market in 1996, a change when production and sales were opened up for competition [28], it opened up a window of opportunity for entering the market with renewable energy. Figure 1 shows an increased amount of CE initiatives started around this time, a majority being wind cooperatives.

Long-term perspective is a key feature and relating to that is the policies and institutional settings. A discussion that had impact on the solar PV development occurred in 2016, when a new taxation for plants over $255 \mathrm{~kW}$ increased by 0.3 SEK per kW, meaning that it became almost impossible to make any money. It was argued from the Swedish Tax Agency that EU regulations stipulated this, but this was disputed by the European Commission and this was changed back after less than a year after serious critique [48]. The episode showed how important legislation and long-term rules are for investment in RE.

Another example showing how changed regulations can halt the development is among wind cooperatives. The development of wind cooperatives was strong during the 1990s and 2000s, but a new tax interpretation of the regulation in 2009 slowed down the development considerably [49] and only a few new cooperatives have been started since then. The change means that those with a business model that could, via an energy company, charge the members self-cost price need to make the members pay tax on the difference compared to market price. The new regulation was debated and criticized since it did not take into consideration the capital investment made by the members but was taken into action in late 2009.

The interviewees do however argue that the taxation has not affected them as much in the end, as it seems like the Swedish Tax Agency does not follow up on the tax returns. The interviewees agreed, however, that the state, through the regulations, has made it more difficult to run a cooperative and that it affects the interest to start cooperatives:

It has been a worse situation since they removed the energy tax exemption [the reduced energy tax-authors' note] but also by taxing the money you are saving on investing in renewable energy .

(Interview 13)

An important economic instrument is the green electricity certificate system. Producers of electricity from RE are eligible for subsidies per produced $\mathrm{kWh}$. The certificates are traded on an open market, and their price fluctuates. In recent years it has been decreased from 0.3 SEK to around 0.15 SEK per produced $\mathrm{kWh}$ [50]. New plants are eligible for 15 years, and after that they will no longer receive certificates [51]. Our interviewees all stated that the system is important, but that the lower compensation has decreased the economic incentives.

We could see in our mapping that 20 wind cooperatives had been discontinued in the last five years, and when interviewing a few of them, it became clear that the decreased economic incentives were among the key factors.

I think it was already in 2013, we lost the electricity certificates, the support system we had had for a number of years. So the compensation we got for the electricity at the time, it was pretty evenly with the costs of operation and maintenance since it also increased for these plants. And then we felt; why should we really do this if we only break even? (Interview 3) 
The low electricity price is another factor, as they have been low since 2012 (between 0.2 and 0.4 SEK per kWh based on the prices at market place NordPool [52]. The investments have been made based on higher electricity prices, and this along with decreasing compensation for electric certificates makes it economically challenging.

But now the prices have been extremely low, and then it is difficult for almost all cooperatives to make any money. It [the electricity prices - authors note] should be around just over forty cents, I think, but it should be somewhere a bit over fifty cents to be really good. And we hope that it will increase later, the electricity market has been a bit strange over the last few years. (Interview 19)

The last factor that affected the discontinued organizations has been that plants have reached their end in technical lifespan. The risks of costly breakdown increases, and they are not able to do the investments based on capital and are not willing to put in more money. Then the fact that the initial key actors express that they are not willing to make the effort any more plays a role. When all these factors have been combined, often around the same time, the drive to continue no longer exists.

Respondent: We sold the first plant, around two and a half years ago, so we only have one of them left, and it will also be sold within a couple of years.

Interviewer: Why?

Respondent: The plant is getting old. The plant that is running is almost 20 years old and the risk of something big happening is pretty big, and then it costs millions. It costs around one million to change the gearbox and we have do not have that kind of money in the cooperative.

Interviewer: And you don't want to build new plants?

Respondent: No, when the plant is sold the cooperative will be discontinued. So we distribute the money that remains among the members and then we end the cooperative. There are some members who think that, "yes, but maybe we should build new wind turbines and continue". Yes, you are welcome to do so, but I do not want to participate. It takes so much time and dedication, and somebody has to be passionate about doing this. (Interview 18)

Another important aspect is that most of the subsidies and tax reliefs in RE investments focus on either private customers or corporations. Investments in solar PVs for these categories receive substantial subsidies (max. 30\% of investment [53]) and corporations and industries have historically been favored both in terms of energy price and taxation. This also reflects the role of the "in-between" organizations, such as CE initiatives: they are not really in contention for these subsidies.

The local aspects have been stressed in the definitions of $C E$ found in the literature $[14,25]$ but although a project might have started out with a local perspective, many have grown and members are often spread throughout a region or, in many cases, throughout Sweden. This is seen most clearly with wind cooperatives, where some own wind-power plants outside of their own municipality, for example, in the case of Slättens Vind and Kvarkenvinden (Interview 14 and 28). This has been possible due to the liberalization, as customers may choose any electricity supplier they want. In the cases of small-scale heating, eco-villages, and rural communities, geographical proximity is crucial for RE production to make sense.

In other countries, previous research has shown that networking activities are seen as important [10], but in Sweden, far from all CE projects are members of an official umbrella or lobby organization or network. The eco-villages have reformed their organization, with an increasing membership, and a few of the wind cooperatives are members in an umbrella organization for wind power owners (not solely for cooperatives), but there is no organization that includes all the different types of initiatives. It was even expressed in interviews that they did not see the point in being members in the umbrella organizations: 
IF: Yes we were members in the Swedish wind power association [Svensk Vindkraftförening], but not anymore.

In: How come?

IF: Yes, so, we have to look at all costs, we need to keep the costs down as much as possible.

(...)

In: Did you experience that they acted in a way so that they could make any difference?

IF: No, but... they have probably tried. You see in reports that they have tried after all. But they haven't really succeeded. (Interview 14)

\section{Discussion}

The development of CE started later in Sweden than in many other countries, and the sector's growth has been slow. One important explanation for this is the structure of the Swedish energy market. The Swedish electricity supply market is dominated by two centralized power solutions, hydro and nuclear power. District heating has been established in 283 of 290 municipalities. This is not unique in Sweden; the Netherlands shows the same patterns historically, but has had a rapid growth of grassroots initiatives in recent years, mainly due to a liberalized energy market, more favorable energy policies and a wider diversity of actors involved in policy making [10]. Some similarities with Sweden exist, e.g. a liberalized energy market, and favorable policies for renewable energy. The difference seems rather to lie in a sense of urgency and the capacities and interests to "take matters into their own hand". Sweden has a long tradition of municipal autonomy and local self-government, and local authorities are often the initiators and operators of environmental initiatives. This has contributed to a tradition where local authorities or energy companies take energy-directed initiatives. Local authorities and energy companies engage and enroll the citizens rather than the opposite, and it is rare that citizens take the initiative.

However, with this in mind, it is interesting to see that projects have been started despite this. As the results have shown, the reasons to start initiatives have varied, spanning from interest in investing in renewable energy, technological interest, self-sufficiency, reduced energy costs, and as in the case of small-scale heating systems and rural communities to take charge of tasks that public authorities cannot handle. The threshold, however, has been high for the initiatives, as support structures have been limited, except general economic support for investment in RE, thus having and gaining substantial knowledge of their own has been crucial. The eco-village pioneers were often highly educated people that had to gain support and cooperate with the local authorities [44]. The motivation and persistence have been very high among all these initiatives.

We argued in the introduction, along with the statements from the EU, that CE plays an important role in engaging citizens in the energy transition and also democratizes energy production. The results show that CE contributes to this development, as citizens engage and invest money in RE, based on conviction and interests in environmental and climate change aspects. However, in quantitative terms, the impact is modest. The largest group, wind cooperatives, engage around 25,000 citizens [40], but the rest of the initiatives have many fewer members. We do, however, argue that they contribute to a variety in ownership, which is just as crucial as the sheer quantity, and may contribute with inspiration for others as well as contributing with local energy production, closer than major market players. Smith et al. [26] argue that when analyzing CE, one needs to go beyond the instrumental focus on drivers and barriers and policy influence, rather to remain open to how $\mathrm{CE}$ embodies new ways of thinking and acting upon energy concerns. The fact that CE exists in Sweden, but also along with the fact that investment in private solar PV plants increases, this further contributes to a diversity, which contributes to a decentralized electricity system.

The CE initiatives in Sweden vary in many ways. The oldest type of CE, eco-villages that blend social and technical innovations based on the skills of the members to satisfy local prerequisites, started as a reaction to the existing regime. Such initiatives also engage willingly in outreach activities 
and welcome, for example, study visits. A few of the eco-villages that started in the 1990s were established by contractors. These had been inspired by the movement, but the lack of involvement from future inhabitants watered down the concept [38]. Other initiatives have been more technical and professionalized, and with lesser involvement from the members, such as wind cooperatives and solar PV cooperatives, as noted in the literature $[10,54]$.

The CE initiatives we have mapped differ when it comes to stated missions. Some projects, such as many of the wind cooperatives, have goals to make cheaper electricity available to the shareholders. In comparison, eco-villages often have missions that are related to social values and a goal of developing a location in an eco-friendly way. The members of an eco-village are expected to engage in the local community in a totally different way than the shareholders in a wind cooperative. Rural communities lie between these extremes: they emphasize making a profit, but stipulate that the profit should be reinvested in the local community.

The lack of coordination through one or several umbrella organizations is a difference compared to other countries [10]. As mentioned above, the respondents stated that they were aware of the organizations, but some expressed that they could not see the benefits of membership. This might give further clues to the slow development in Sweden, as a gathering force would arguably be an advantage for spreading knowledge and give support for new cooperatives.

The future of CE in Sweden is uncertain. The amount of CE in several other countries has steadily grown, but the Swedish situation is in flux. The insecurity considering regulations, as seen in tax cases considering wind cooperatives and solar cooperatives, are examples of this. The trend of discontinued wind cooperatives is one clear example, and it becomes clear how important the combination of economic support, energy prices, and commitment of key actors is.

In contrast, some new eco-villages are under development, often with a connection to other movements, such as permaculture, and some solar cooperatives have been started. Individual (home-owner) investment in solar PVs is, however, a competing form of organization, and has increased more rapidly than collective initiatives [55].

\section{Conclusions}

Sweden has many CE initiatives, but the nature of Swedish society and the energy supply system ensure that they are fewer than in many other countries. Approximately 140 active CE initiatives have been identified, 78 of which are wind cooperatives, 32 eco-villages, 10 small-scale heating systems, nine solar PV cooperatives, and eight rural communities with a clear CE focus.

Conditions for CE have not been ideal in Sweden, considering the structure of the energy market and strong involvement of municipalities. Despite this, CE project have developed across Sweden, with groups of citizens showing considerable perseverance and knowledge. These are groups that have either a specific interest in renewable energy, want to move towards self-sufficiency, want to reduce energy costs, or have to solve other local problems. They are also committed to take matters into their own hands and try to make an impact.

Earlier research has emphasized a bottom-up perspective on CE programs, where the local community initiates an environmental project such as collectively owned PV panels $[18,25]$. In a Swedish context it has been common that local authorities or energy companies start energy-directed initiatives and enroll citizens. Otherwise, these initiatives have the same characterizations as CE in other countries, such as local participation and results that benefit a local community [17]. Additionally, Lauber [56] has discussed that a significant part of the community energy projects in Germany and Denmark had stemmed from businesses like farmers' cooperatives. The ownership of these communities was shared with not only the public, but also private companies. This indicates that it is of less importance who is initiating a CE, and that the local community can be just as engaged when other actors start up an initiative and later on engage in a project. This supports the more pragmatic view of Walker et al. [5] on CE programs. One criticism of such a pragmatic stance would be that such an ownership structure would undermine the very premise of $C E$ and limit the option for $C E$ to be a 
counterpoint to the incumbent system of for-profit centralized energy. However, in a Swedish context we would argue that established CE contributes to a decentralized system even when ownership is mixed. There are few other alternatives that engage and involve the citizens in the energy system.

Wirth [3] emphasizes that the establishment of CE is one way to make energy generation and consumption more local. Becker and Kunze [22] and Kunze and Becker [21] state however that CE does not need to be geographically restricted to a local place, but can be regional and national. In Sweden many CE initiatives have not restricted their membership to local citizens; they invite people from all over Sweden to be part of the initiative. Even if CE is not local in the way Wirth [3] meant, it can still contribute to increased interest and engagement in energy production and consumption by the members. For instance, even if a wind turbine is located in another region than where the shareholder lives, the same interest and engagement in the production can be developed. A wind turbine's production can be followed on a website, for instance, which can be just as satisfying as if it were located close to home.

Future research may more deeply examine the cultural embeddedness of CE initiatives, and the personal abilities that locally-engaged volunteers must have, to be able to navigate in the complex socio-technical landscape.

Author Contributions: Conceptualization: D.M. and J.P.; data curation: D.M. and J.P; formal analysis: D.M. and J.P; investigation" D.M. and J.P; methodology: D.M. and J.P; project administration: D.M. and V; writing—original draft: D.M. and J.P; writing - review and editing: D.M. and J.P.

Funding: This research was funded by Swedish Research Council Formas (Svenska Forskningsrådet Formas), grant number [2014-1715], as part of the JPI Climate Joint Call for Transnational Collaborative Research Projects, Societal Transformation in the Face of Climate Change.

Acknowledgments: The authors would like to thank research group STRIPE at Linköping University and two anonymous reviewers for valuable comments on the paper.

Conflicts of Interest: The authors declare no conflict of interest.

Appendix A

\begin{tabular}{|c|c|c|}
\hline Interview No. & Title & Organization \\
\hline 1 & Part-owner & Non-government hydro power company \\
\hline 2 & Chair & Non-government biogas organization \\
\hline 3 & Chair & Non-government wind power cooperative 1 \\
\hline 4 & Board member & Umbrella organization eco-villages \\
\hline 5 & Founders (2 persons) & Eco-village 1 \\
\hline 6 & Board member & Eco-village 2 \\
\hline 7 & Board member & Eco-village 3 \\
\hline 8 & Chair & Non-government heating company 1 \\
\hline 9 & Project manager & Umbrella organization rural development \\
\hline 10 & Chair & Eco-village 4 \\
\hline 11 & Board member & Eco-village 5 \\
\hline 12 & Cheif marketing officer & Non-government solar organization 1 \\
\hline 13 & Chair & Non-government wind power cooperative 2 \\
\hline 14 & Chair & Non-government wind power cooperative 3 \\
\hline 15 & Board member & Non-government wind power cooperative 4 \\
\hline 16 & Board member & Eco-village 6 \\
\hline 17 & Project manager & Rural community 1 \\
\hline 18 & Treasurer & Non-government wind power cooperative 5 \\
\hline 19 & Chair & Non-government wind power cooperative 6 \\
\hline 20 & Former chair & Umbrella organization sustainable development \\
\hline 21 & Chair & Rural community 2 \\
\hline 22 & $\mathrm{CEO}$ & Non-government wind power cooperative 7 \\
\hline
\end{tabular}




\begin{tabular}{|c|c|c|}
\hline 23 & Chair & Non-government wind power cooperative 8 \\
\hline 24 & Co-founder and CEO energy company & Non-government solar organization 2 \\
\hline 25 & Chair & Non-government solar organization 2 \\
\hline 26 & Chair & Umbrella organization renewable energy \\
\hline 27 & Board member & Non-government solar organization 3 \\
\hline 28 & Former CEO & Non-government wind power cooperative 9 \\
\hline 29 & Engineer energy company & Non-government solar organization 4 \\
\hline 30 & Chair & Eco-village 7 \\
\hline 31 & Unit manager & Eco-village 7 \\
\hline 32 & Chair & Non-government solar organization 5 \\
\hline 33 & Board member & Non-government solar organization 6 \\
\hline 34 & Founder and project manager & Eco-village 8 \\
\hline 35 & Founder & Eco-village 9 \\
\hline 36 & Chair & Umbrella organization wind cooperatives \\
\hline 37 & Vice Chairman & Non-government wind power cooperative 10 \\
\hline 38 & Part-owner & Non-government heating company 2 \\
\hline 39 & Chair & Non-government wind power cooperative 11 \\
\hline 40 & $\begin{array}{l}\text { Sales officer and manager for renewable } \\
\text { energy ( } 2 \text { persons) }\end{array}$ & Government energy company \\
\hline 41 & Chair & Non-government solar organization 7 \\
\hline 42 & Founder & Non-government solar organization 8 \\
\hline 43 & Former Chair & Eco-village 10 \\
\hline
\end{tabular}

\section{References}

1. European Commission. A Framework Strategy for a Resilient Energy Union with a Forward-Looking Climate Change Policy; COM/2015/080 final; European Commission: Brussels, Belgium, 2015; pp. 1-21.

2. European Commission. Third Report on the State of the Energy Union; COM/2015/080 final; European Commission: Brussels, Belgium, 2017.

3. Wirth, S. Communities matter: Institutional preconditions for community renewable energy. Energy Policy 2014, 70, 236-246. [CrossRef]

4. Kooij, H.J.; Oteman, M.; Veenman, S.; Sperling, K.; Magnusson, D.; Palm, J.; Hvelplund, F. Between grassroots and treetops: Community power and institutional dependence in the renewable energy sector in Denmark, Sweden and the Netherlands. Energy Res. Social Science 2018, 37, 52-64. [CrossRef]

5. Walker, G.; Hunter, S.; Devine-Wright, P.; Evans, B.; Fay, H. Harnessing community energies: explaining and evaluating community-based localism in renewable energy policy in the UK. Glob. Environ. Politi. 2007, 7, 64-82. [CrossRef]

6. Seyfang, G.; Park, J.J.; Smith, A. A thousand flowers blooming? An examination of community energy in the UK. Energy Policy 2013, 61, 977-989. [CrossRef]

7. Heiskanen, E.; Jalas, M.; Rinkinen, J.; Tainio, P. The local community as a "low-carbon lab": Promises and perils. Environ. Innov. Soc. Transit. 2015, 14, 149-164. [CrossRef]

8. Mignon, I. Inducing Large-Scale Diffusion of Innovation: An Integrated Actor-and System-Level Approach; Linköping University Electronic Press: Linköping, Sweden, 2016.

9. Mignon, I.; Rudinger, A. The impact of systemic factors on the deployment of cooperative projects within renewable electricity production - An international comparison. Renew. Sust. Energ. Rev. 2016, 65, 478-488. [CrossRef]

10. Oteman, M.; Kooij, H.-J.; Wiering, M.A. Pioneering renewable energy in an economic energy policy system: the history and development of Dutch grassroots initiatives. Sustainability 2017, 9, 550. [CrossRef]

11. DECC. Community Energy Strategy: Full Report; Change, D.o.E.C., Ed.; Department of Energy and Climate Change: London, England, 2014.

12. Yamamoto, Y. The role of community energy in renewable energy use and development. Renew. Energy Environ. Sus. 2016, 1, 18. [CrossRef]

13. Ornetzeder, M.; Rohracher, H. Of solar collectors, wind power, and car sharing: Comparing and understanding successful cases of grassroots innovations. Glob. Environ. Change-Human Policy Dimens. 2013, 23, 856-867. [CrossRef] 
14. Martiskainen, M. The role of community leadership in the development of grassroots innovations. Environ. Innov. Soc. Transit. 2017, 22, 78-89. [CrossRef]

15. Seyfang, G.; Longhurst, N. Growing green money? Mapping community currencies for sustainable development. Ecol. Econ. 2013, 86, 65-77. [CrossRef]

16. Walker, G.; Devine-Wright, P. Community renewable energy: What should it mean? Energy policy 2008, 36, 497-500. [CrossRef]

17. Rogers, J.C.; Simmons, E.A.; Convery, I.; Weatherall, A. Public perceptions of opportunities for community-based renewable energy projects. Energy Policy 2008, 36, 4217-4226. [CrossRef]

18. Reeves, A.; Lemon, M.; Cook, D. Jump-starting transition? Catalysing grassroots action on climate change. Energy Eff. 2014, 7, 115-132. [CrossRef]

19. Hielscher, S.; Seyfang, G.; Smith, A. Grassroots innovations for sustainable energy: Exploring niche development processes among community energy initiatives. In Innovations in Sustainable Consumption: New Economics, Socio-Technical Transitions, and Social Practices; Cohen, M., Brown, H., Vergragt, P., Eds.; Edward Elgar Publishing: Cheltenham, England, 2013; pp. 133-158.

20. Oteman, M.; Wiering, M.; Helderman, J.-K. The institutional space of community initiatives for renewable energy: A comparative case study of the Netherlands, Germany and Denmark. Energy Sus. Soc. 2014, 4, 11. [CrossRef]

21. Kunze, C.; Becker, S. Collective ownership in renewable energy and opportunities for sustainable degrowth. Sus. Sci. 2015, 10, 425-437. [CrossRef]

22. Becker, S.; Kunze, C. Transcending community energy: Collective and politically motivated projects in renewable energy (CPE) across Europe. People Place Policy Online 2014, 8. [CrossRef]

23. Bauwens, T.; Gotchev, B.; Holstenkamp, L. What drives the development of community energy in Europe? The case of wind power cooperatives. Energy Res.Soc. Sci. 2016, 13, 136-147. [CrossRef]

24. Tarhan, M. Renewable energy cooperatives: A review of demonstrated impacts and limitations. J. Entrep. Organ. Divers. 2015, 4, 104-120. [CrossRef]

25. Klein, S.J.; Coffey, S. Building a sustainable energy future, one community at a time. Renew. Sus. Energy Rev. 2016, 60, 867-880. [CrossRef]

26. Smith, A.; Hargreaves, T.; Hielscher, S.; Martiskainen, M.; Seyfang, G. Making the most of community energies: Three perspectives on grassroots innovation. Environ. Plann. A Economy Space 2016, 48, 407-432. [CrossRef]

27. Swedish Energy Agency. Energiindikatorer 2017-Uppföljning av Sveriges energipolitiska mål; Report; Swedish Energy Agency: Eskilstuna, Sweden, 2017.

28. Magnusson, D. District Heating in A Liberalized Energy Market: A New Order?-Planning and Development in the Stockholm Region, 1978-2012. Ph.D. Thesis, Linköping University Press, Linköping, Sweden, 2013.

29. Palm, J.; Tengvard, M. Motives for and barriers to household adoption of small-scale production of electricity: Examples from Sweden. Sus. Sci. Pract. Policy 2011, 7. [CrossRef]

30. Bergek, A.; Mignon, I.; Sundberg, G. Who invests in renewable electricity production? Empirical evidence and suggestions for further research. Energy Policy 2013, 56, 568-581. [CrossRef]

31. Hossain, M. Grassroots innovation: A systematic review of two decades of research. J. Clean. Prod. 2016, 137, 973-981. [CrossRef]

32. Swedish Energy Agency. Energiläget 2017; Swedish Energy Agency: Eskilstuna, Sweden, 2017.

33. Werner, S. District heating and cooling in Sweden. Energy 2017, 126, 419-429. [CrossRef]

34. Baas, L.; Magnusson, D.; Mejía-Dugand, S. Emerging Selective Enlightened Self-Interest Trends in Society: Consequences for Demand and Supply of Renewable Energy; Linköping University Press: Linköping, Sweden, 2014.

35. Krantz, H. Matter that matters: A study of household routines in a process of changing water and sanitation arrangements. Ph.D. Thesis, Linköping University Press, Linköping, Sweden, 2005.

36. Palm Lindén, K. Ekologi och Vardagsliv: En Studie av toå Ekobyar: Slutrapport; AFR, Naturvårdsverket: Stockholm, Sweden, 1998; Volume 198.

37. Berg, P.G. Sustainability resources in Swedish townscape neighbourhoods: Results from the model project Hågaby and comparisons with three common residential areas. Landsc. Urban Plan. 2004, 68, $29-52$. [CrossRef] 
38. Berg, P.G.; Cras-Saar, M.; Saar, M. Living Dreams: Om Ekobyggande-en Hållbar Livsstil; Scapa: Nyköping, Sweden, 2002.

39. Bartusch, C. Andelsägande i Solel ur ett Hushållsperspektiv. Elforsk rapport 11:34. 2011. Available online: https: / / dokodoc.com/andelsgande-i-solel-ur-ett-hushllsperspektiv.html (accessed on 15 February 2019).

40. Wizelius, T. Vindkraft Tillsammans—Handbok för Vindkooperativ; Vindform förlag: Stockholm, Sweden, 2012.

41. Skälegård, A. Inventering av Projekt för Lokal Energiproduktion från Jordbruk; Hela Sverige ska leva: Stockholm, Sweden, 2004. Available online: https://helasverige.se/fileadmin/user_upload/HSSL_Kansli/PDF/ Informationsmaterial/inventering.pdf/ (accessed on 15 February 2019).

42. Corbin, J.M.; Strauss, A.L. Basics of Qualitative Research: Techniques and Procedures for Developing Grounded Theory; SAGE: Thousand Oaks, CA, USA, 2015.

43. Kvale, S.; Brinkmann, S. Den Kvalitativa Forskningsintervjun; Studentlitteratur: Lund, Sweden, 2014.

44. Magnusson, D. Going back to the roots: The fourth generation of Swedish eco-villages. Scott. Geogr. J. 2018, 134, 122-140. [CrossRef]

45. Palm, J. Makten över energin: Policyprocesser i två kommuner 1977-2001.; Linköping University: Linköping, Sweden, 2004.

46. Ibsen, H. Walk the talk for sustainable everyday life: Experiences from eco-village living in Sweden. In Environmental Policy and Household Behaviour: Sustainability and Everyday Life; Söderholm, P., Ed.; Earthscane: London, UK, 2010; pp. 129-148.

47. Swedish Energy Agency. Ekonomiska Styrmedel $i$ Energisektorn. En Utvärdering av Dess Effekter på Koldioxidutsläppen från 1990; ER 2006:06; Swedish Energy Agency: Eskilstuna, Sweden, 2006.

48. Tidningarnas, T. Regeringen pudlar om solskatten. Svenska Dagbladet. 21 November 2016. Available online: https:/ / www.svd.se/regeringen-sanker-nyss-hojd-solskatt (accessed on 15 February 2019).

49. Wizelius, T. Vindkraft $i$ Teori Och Praktik, 3rd ed.; Studentlitteratur: Lund, Sweden, 2015.

50. Swedish Energy Agency. Statistik Elcertifikat. Available online: https://cesar.energimyndigheten.se/ WebPartPages/SummaryPage.aspx (accessed on 1 February 2019).

51. Swedish Energy Agency. Vindkraftens del av elförsörjningen. Available online: http:/ / www.energimyndigheten.se/fornybart/vindkraft/marknadsstatistik/ny-sida/vindkraftensdel-av-elforsorjningen-2015/ (accessed on 17 December 2018).

52. Swedish Energy Agency. Elpriser. Available online: http://www.energimyndigheten.se/ nulagetpaelmarknaden/Elpriser/ (accessed on 16 January 2019).

53. Swedish Energy Agency. Investeringsstöd. Available online: http://www.energimyndigheten.se/fornybart/ solelportalen/vilka-stod-och-intakter-kan-jag-fa/sa-har-ansoker-du-om-investeringsstod/ (accessed on 17 December 2018).

54. Seyfang, G.; Hielscher, S.; Hargreaves, T.; Martiskainen, M.; Smith, A. A grassroots sustainable energy niche? Reflections on community energy in the UK. Environ. Innov. Soc. Transit. 2014, 13, 21-44. [CrossRef]

55. Palm, J. Household installation of solar panels-Motives and barriers in a 10-year perspective. Energy Policy 2018, 113, 1-8. [CrossRef]

56. Lauber, V. REFIT and RPS: Options for a harmonised Community framework. Energy Policy 2004, 32, 1405-1414. [CrossRef]

(C) 2019 by the authors. Licensee MDPI, Basel, Switzerland. This article is an open access article distributed under the terms and conditions of the Creative Commons Attribution (CC BY) license (http://creativecommons.org/licenses/by/4.0/). 